UDC 94(470)“1941/1945”(574-25)

Submitted: 20.06.2019

LBC 63/3(2)622-2(2Каз-2Алм)

Accepted: 20.11.2019

\title{
MILITARY ROUTINE IN REAR CITY IN 1941-1945 (CASE OF ALMA-ATA) ${ }^{1}$
}

\author{
Roza S. Zharkynbayeva \\ Al-Farabi Kazakh National University, Almaty, Republic of Kazakhstan \\ Nadezhda V. Dulina \\ Volgograd State University, Volgograd, Russian Federation \\ Evgeniya V. Anufrieva \\ Volgograd State Technical University, Volgograd, Russian Federation
}

\begin{abstract}
Introduction. The purpose of this article is to highlight the features of daily life in cities of rearguard during World War II (as exemplified by Alma-Ata), the strategy of survival of people in the extremely difficult war years (1941-1945). Methods and materials. The study of features of daily city life in the extreme wartime from the point of view of the systematic approach is a basis for analytical generalizations and scientific hierarchization of the collected historical material. The system method is inextricably linked with the macro-and micro-approach, the combination of which allows to reveal the general and the particular in the studied processes, both from the point of view of the state-institutional view - "from above" and from the point of view of their ordinary participants and witnesses - "from below". The micro-level of the research allows to study the problem in different projections: economic, political, socio-cultural one, helps to show the humanitarian dimension of the city daily life in wartime. Using the multifaceted approach to the formation of the research source base, introducing new declassified archival documents into scientific circulation allows to restore the daily life of Alma-Ata during the Great Patriotic War, to approach its objective and multidimensional understanding. As the main group of sources the authors use documents extracted from the archives of the Republic of Kazakhstan, in particular, the Central State Archive of the Republic of Kazakhstan (Almaty) (CSA RK), the National archive of Kazakhstan (Astana) (NA RK). Analysis and Results. The result of the research is a demonstration of the daily life of ordinary citizens who bravely endured all the hardships of war both at work and at home, in the family, helping fellow citizens who were evacuated to the city during the war.
\end{abstract}

Key words: Great Patriotic War, daily life, military daily life, rearguard, citizens, evacuation.

Citation. Zharkynbayeva R.S., Dulina N.V., Anufrieva E.V. Military Routine in Rear City in 1941-1945 (Case of Alma-Ata). Vestnik Volgogradskogo gosudarstvennogo universiteta. Seriya 4. Istoriya. Regionovedenie. Mezhdunarodnye otnosheniya [Science Journal of Volgograd State University. History. Area Studies. International Relations], 2020, vol. 25, no. 1, pp. 97-108. (in Russian). DOI: https://doi.org/ $10.15688 / \mathrm{jvolsu} 4.2020 .1 .8$

\section{ВОЕННАЯ ПОВСЕДНЕВНОСТЬ В ГОРОДАХ ТЫЛА В 1941-1945 ГГ. (НА ПРИМЕРЕ Г. АЛМА-АТЫ) ${ }^{1}$}

\author{
Роза Сейдалиевна Жаркынбаева \\ Казахский национальный университет им. аль-Фараби, г. Алматы, Республика Казахстан
}

Надежда Васильевна Дулина

Волгоградский государственный университет, г. Волгоград, Российская Федерация 


\section{Евгения Владимировна Ануфриева}

Волгоградский государственный технический университет, г. Волгоград, Российская Федерация

Аннотация. Цель данной статьи - осветить особенности военной повседневной жизни тылового города (на примере г. Алма-Аты), стратегии выживания людей в чрезвычайно сложные военные годы (1941-1945 гг.). Изучение особенностей повседневной жизни города в экстремальное военное время с точки зрения системного подхода является основой для аналитических обобщений и научной иерархизации собранного исторического материала. Системный метод находится в неразрывной связи с макро- и микроподходом, сочетание которых позволило выявить общее и частное в изучаемых процессах как с точки зрения государственноинституционального взгляда - «сверху», так и с точки зрения их рядовых участников и очевидцев - «снизу». Микроуровень исследования позволяет изучить проблему в различных проекциях: экономической, политической, социокультурной, помогает показать гуманитарное измерение повседневной жизни города в военное время. Применение комплексного подхода к формированию источниковой базы исследования, введение в научный оборот новых рассекреченных архивных документов позволяет восстановить повседневную жизнь г. Алма-Аты в годы Великой Отечественной войны, приблизиться к объективному и многомерному его пониманию. В качестве основной группы источников представлены документы, извлеченные из архивов Республики Казахстан, в частности, Архива Президента Республики Казахстан (г. Алматы) (АП РК), Центрального государственного архива Республики Казахстан (г. Алматы) (ЦГА РК), Национального архива РК (г. Астана) (НА РК). В результате проделанной работы с документами показана повседневная жизнь простых горожан, которые мужественно переносили все тяготы военного времени как на работе, так и в быту, в семье, помогая при этом эвакуированным в город на время войны согражданам. Представленный материал является результатом совместной работы авторов: под руководством Р.С. Жаркынбаевой выстроена общая концепция работы, обобщены полученные данные, проведена работа в архивах Республики Казахстан, Н.В. Дулиной систематизированы литературные данные и подготовлен основной текст рукописи; Е.В. Ануфриевой проведен анализ большинства документов и обобщены результаты, оформлен общий текст.

Ключевые слова: Великая Отечественная война, повседневность, военная повседневность, тыл, горожане, эвакуация.

Цитирование. Жаркынбаева Р. С., Дулина Н. В., Ануфриева Е. В. Военная повседневность в городах тыла в 1941-1945 гг. (на примере г. Алма-Аты) // Вестник Волгоградского государственного университета. Серия 4, История. Регионоведение. Международные отношения. -2020. - T. 25, № 1. - С. 97-108. - DOI: https:// doi.org/10.15688/jvolsu4.2020.1.8

Введение. Великая Отечественная война остается одним из тех событий, память о которых соединяет суверенные государства сегодня, а в то время одну страну, которая выстояла благодаря людям, защищавшим ее на фронте, людям, отдававшим в тылу все силы для Победы. Сегодня у исследователей из стран постсоветского пространства, в данном случае из Казахстана и России, есть возможность открыть новые страницы в истории Великой Отечественной войны, во многом благодаря работе с новыми архивными материалами, по новому увидеть то, как люди в военное время оставались человечными. Примерами подобных исследований являются работы Т.П. Хлыниной [26], Р.С. Жаркынбаевой [6] и др.

Методы и материалы. В центре внимания данной работы оказалась военная повседневность городов тыла на примере города Алма-Аты. Наибольшую важность для ис- следования представляют документы Архива Президента Республики Казахстан (г. Алматы), бывшего партийного архива (АП РК), в частности документы, хранящиеся в фондах № 708 (Центральный комитет КП(б) Казахстана) и № 725 (Комиссия партийного контроля при ЦК ВКП(б) Уполномоченного по Казахской ССР) Архива Президента РК.

Существуют разные подходы к изучению проблемы повседневной жизни во время Великой Отечественной войны. Некоторые подразумевают под «повседневностью» главным образом сферу частной жизни, охватывающей вопросы семьи, дома, быта, воспитания детей, досуга, дружеских связей и круга общения. Другие в первую очередь рассматривают жизнь трудовую, те модели поведения и отношения, которые возникают на рабочем месте. Например, Ш. Фицпатрик предлагает первостепенное внимание уделять обиходной практике, то есть тем формам поведения и 
стратегиям выживания и продвижения, которыми пользуются люди в специфических социально-политических условиях [25, с. 7].

Н. Лебина предлагает использовать в качестве методологического подхода к изучению советской повседневности дихотомию «норма/аномалия», которая не только существует в сфере обыденной жизни, но и применяется как метод построения разнообразных научных конструктов [10, с. 7].

Город Алма-Ата стал одним из приемных пунктов СССР по размещению эвакуированных заводов, фабрик, научных и культурно-просветительских учреждений, эвакуированных госпиталей и эвакуированного населения.

В нашей работе полученная в архивах информация разделена на несколько блоков, каждый из которых открывает страницы истории военной повседневности алмаатинцев: первый касается изменения жизни города в связи с началом войны, а именно, с переходом производства на военные рельсы. Второй связан с освещением вопросов о направлении, размещении и обеспечении жизни эвакуированного в город населения, решением всего комплекса жилищных, продовольственных, бытовых и других проблем. Третий касается эвакуированных госпиталей, медицинского персонала и инвалидов войны, оказавшихся в эвакуации, четвертый - о трудовом энтузиазме алмаатинцев. Архивные документы позволили дополнить уже широко известные факты трудового и простого человеческого участия горожан в судьбе страны в тяжелое время, открыв то, что жизнь и люди, живущие ею, остаются сами собой даже в войну.

Анализ. Страшное слово «война» тысячи алмаатинцев услышали 22 июня 1941 г., когда отправились в горы на строительство Комсомольского озера. 22 июня 1941 г. в парке культуры и отдыха им. М. Горького состоялся городской митинг. В первый же день войны горожане проявили свой патриотизм, в горвоенкоматы поступили многочисленные заявления с просьбой отправить на фронт, были созданы 4 призывных пункта [17, л. 1].

На основании решения ЦК КП(б) К от 29 июня 1941 г. в г. Алма-Ате создан дом обороны, который должен был стать основ- ным центром по развертыванию оборонномассовой работы трудящихся города АлмаАты [3, л. 71].

С началом войны мирный облик 2. Алма-Аты стремительно менялся. В окрестностях строились полигоны для обучения стрельбе и искусству современного боя. Появилась сеть кружков и курсов по подготовке медсестер, было создано 11 школ и 26 краткосрочных медицинских курсов, организовано 37 санпостов. Были созданы группы по подготовке снайперов, радистов, телеграфистов, шоферов и бойцов других специальностей. В военное время широко развернулось в городе строительство предприятий. В 1941 г. в строй вступили швейная фабрика № 2 и меховая фабрика, в 1942 г. - колбасный завод, хлебозавод № 1, трамвайная линия между станцией Алма-Ата-1 и Алма-Ата-2, в 1943 г. чаеразвесочная фабрика и ряд предприятий промкооперации [17, л. 1-2].

Началась перестройка работы промышленных предприятий на военный лад, был осуществлен переход к производству оборонной продукции. Швейные, меховые фабрики, артели и промкомбинаты начали шить шинели, гимнастерки, брюки, белье, пилотки. Кожевенные предприятия приступили к выделке овчин для изготовления полушубков и обуви. Обувные фабрики и мастерские артелей стали производить армейские сапоги, ботинки и валенки [17, л. 1].

Только за 1941-1943 гг. здесь было размещено оборудование 34 заводов, фабрик и цехов отдельных предприятий, в том числе завод тяжелого машиностроения, электротехнический завод, механический завод № 3, вагоноремонтный завод, Московская суконная фабрика, хлопкопрядильная фабрика, трикотажная, кондитерская фабрики [17, л. 1].

Распределение прибывших эшелонов производилось Эвакуационным отделом при СНК КазСР и уже по областям и районам велся эвакуационными пунктами, которые на октябрь 1941 г. были в каждом областном центре, в том числе и в г. Алма-Ате [5, л. 44].

Приток эвакуированного населения в тыловые районы, в том числе и в Алма-Ату, был осложнен также и критическим недостатком кадров и материальных средств для удовлетворения базовых потребностей эвакуиро- 
ванного населения. В работе эвакуационных пунктов имелись серьезные недостатки, остро стояла проблема нехватки кадров работников. По данным на 1 марта 1943 г. по АлмаАтинскому эвакуационному пункту были предусмотрены 34 штатные единицы, фактически работали 11 человек [22, л. 14].

Инфраструктура станций и вокзалов города не была рассчитана на обслуживание больших людских потоков. Серьезной проблемой стала организация питания, отсутствие кипятка, горячей пищи. Большие очереди, в несколько сот человек, были довольно распространенным явлением.

Один из тяжелых случаев нашел отражение в «Справке о состоянии прибывшего оборудования и людей на станцию Алма-Ата, Отрожского вагоноремонтного завода им. Тельмана». Вечером 5 декабря 1941 г. прибыли на станцию Алма-Ата - 124 вагона с людьми в количестве 879 человек, в том числе 60 человек рабочих и 4 вагона с материалами и оборудованием, которые стали разгружать. Прибывшие люди оставались жить в вагонах. Как отмечалось в документе, при осмотре ряда вагонов было установлено, что люди жили в большинстве вагонов тесно, имелись случаи заболеваний, особенно детей - дизентерией и другими невыясненными болезнями. Например, в одном из вагонов находились 45 человек, в нем 5-й день лежал больной мальчик 15 лет с температурой, заболела девочка 1 года 7 месяцев дизентерией, но врача не было, и девочка умерла. На 26 декабря в вагонах имелось 23 человека больных, большинство из них дети, которые болели дизентерией $[21$, л. 116, 118]. Эвакуированные с 5 декабря жили на станции Алма-Ата, в бане не были, кроме 300 грамм хлеба на человека ничего не получали, кипятку (который они получили во время прихода поездов) им не давали. Как следует из документов, должная медицинская помощь им не оказывалась, было 4 случая смертности (из них трое детей, которые умерли от дизентерии, воспаления легких) [21, л. 119].

Данная ситуация возникла из-за путаницы и неразберихи в связи с несогласованностью действий Народного комиссариата путей сообщения (НКПС), Отрожского завода и ст. Алма-Ата-1. В частности, начальником
Отрожского завода с 5 по 26 декабря были направлены 2 телеграммы, в которых было дано указание разгрузку не производить до особого распоряжения [21, л. 119-120]. После результатов проверки органами партийного контроля были привлечены к ответственности ответственные лица, и помощь эвакуированным была оказана.

В то же время Алма-Ата стал одним из наиболее привлекательных для эвакуации советского населения городов. На 29 августа 1941 г. в г. Алма-Ату прибыли 1379 эвакуированных, мужчин - 463, женщин - 916. Из них мужчин от 16 до 59 лет -221 , женщин от 16 до 54 лет - 674, детей до 7 лет - 281, детей от 7 до 15 лет - 196. Из Московской области 647 , Ленинградской - 69, прифронтовой полосы - 663 [19, л. 70]. Как видно из документа, всего лишь за два месяца с начала войны в городе осело почти 1400 эвакуированных.

Женщины г. Алма-Аты на митинге выступили с призывом «Ко всем женщинам Казахстана, колхозницам, работницам, учителям, медработникам, ко всем членам профессиональных союзов, матерям и старшим сестрам школьников Казахстана, ко всем патриоткам Советской Родины!» помочь эвакуированным детям. Было предложено провести следующие мероприятия:

a) создать «Советы женского актива помощи детям»;

б) взять к себе в семью на содержание эвакуированного ребенка;

в) в праздничные и выходные дни приглашать в гости к себе ребят, заботиться об их развлечении, посещать с ними кино, концерты, детские спектакли и т. д., делать ребятам посильные подарки;

г) отчислить однодневный заработок и закупать необходимое, организовать сбор одежды и белья для эвакуированных детей $[18$, л. 21].

Учитывая то, что в условиях военного времени, когда практически все ресурсы направлялись на нужды фронта, и местное население само недоедало, это было проявлением истинной человечности.

В целом по городу Алма-Ате в сводке о количестве прибывшего эвакуированного населения в Казахскую ССР по состоянию на 1 марта 1943 г. значилось 26304 человека, но при этом отмечалось, что эти сведения «не 
полные, ввиду отсутствия точного учета как количества прибывшего населения, так и его трудоустройства» [20, л. 2]. Таким образом, очевидно, что прибывших было куда больше.

Размещение и трудоустройство эвакуированного населения в г. Алма-Ате велось согласно Постановления ЦК КП(б) и СНК КазССР от 1 декабря 1941 г. «О трудовом использовании и бытовом обслуживании эвакуированного населения в Казахской ССР» и Постановления СНК КазССР от 31 декабря 1941 г. № 948 «О строительстве упрощенных жилищных, коммунальных и бытовых помещений для эвакуированного населения».

Самой главной задачей в ряду мер по приему и обустройству эвакуированного населения, для республиканских органов власти, была задача по обеспечению жильем. Этот вопрос стоял наиболее остро, поскольку в целом для всех советских республик положение с жильем и в довоенное время было катастрофическим. Как известно, большая часть населения городов в СССР жила в коммуналках, и проблема нехватки жилищного фонда стояла остро. В тыловых районах СССР для расселения эвакуированных продолжалась практика «уплотнения» жилищного фонда, то есть эвакуированных подселяли в жилища местных жителей.

Проводилась политика выселения из городов в сельскую местность семей, не связанных со стратегическими производственными задачами, некоторых социальных групп, или так называемых «неблагонадежных».

В рассекреченных архивных документах по размещению эвакуированного населения в г. Алма-Ате отмечалось: «В целях быстрейшего очищения города от социально-вредных элементов, подпадающих под действие Постановления СНК № 1667 от 16/IX-1940 г., выселять из города не в 10-дневный срок, как это было предусмотрено вышеуказанным постановлением, а в 3-дневный срок» [1, л. 19].

Выражали свою поддержку и вносили свои предложения по ужесточению политики и некоторые представители общественности города. В частности, журналист И.М. Санович в заявлении от 1 августа 1942 г., адресованном Уполномоченному комиссии Партийного контроля при ЦК ВКП(б) по КазССР, копия: Наркому внутренних дел СССР Л.П. Бе- рия, изложил «крупные недостатки в деле охраны революционного порядка в столице КазССР г. Алма-Ате». «В городе имеет распространение антисоветская агитация, пропаганда вражды между отдельными народами $<$..> несмотря на то, что Алма-Ата является режимным городом, в столице проживает большое число ссыльно-переселенцев, семей арестованных, раскулаченных и тому подобных...». Для выхода из сложившейся ситуации он вносил следующие предложения:

«1. О выселении в отдаленные районы Казахстана раскулаченных, ссыльно-переселенцев и прочих лиц, проживание которых в городе Алма-Ате недопустимо / прошу вспомнить мудрую меру Союзного правительства летом прошлого года о выселении целой категории лиц из бывшей республики Нижнего Поволжья.

2. Об организации судебного преследования с откликом через печать, хотя бы некоторых изобличенных в антисоветской и антисемитской пропаганде лиц...» [8, л. 176176 об.].

Таким образом, И.М. Санович предлагал еще более ужесточить тоталитарную политику, а трагедию целого народа - немцев, которые были несправедливо обвинены как «неблагонадежный народ» и насильственно переселены, считал «мудрой мерой».

Несмотря на то что г. Алма-Ата являлся режимным городом, что затрудняло прописку эвакуированных, желающих в нем поселиться было очень много. Из записей бесед с эвакуированными и просмотров заявлений о прописке можно увидеть большую привлекательность города для них. Так, гражданка Симакова выехала в порядке эвакуации из г. Воронежа и следовала санитарным поездом до г. Семипалатинска, климатические условия города «ей не понравились» и по ее просьбе семипалатинский эвакопункт 28 октября 1941 г. выдал ей направление в г. Алма-Ату, где она и просила ее прописать. Жена военнослужащего гр. Шварцапель с ребенком и матерью была эвакуирована из Днепропетровска в Пятигорск. Из Пятигорска, согласно пропуска коменданта, она въехала в г. Омск, а из г. Омска приехала в г. Алма-Ату и просила прописать ее в квартире брата, проживающего в г. Алма-Ате. Гр. Е.И. Табак с сани- 
тарным поездом сопровождала раненого мужа до Новосибирска, из Новосибирска приехала в г. Алма-Ату и также просила ее прописать [14, л. 87].

Эвакуированный из г. Таллина М.Б. Аронштам писал: «Прошу помочь мне получить прописку в г. Алма-Ате, и тем самым дать возможность своими знаниями и опытом быть полезным общему делу» [9, л. 71]. Или, как писала эвакуированная из г. Кишинев П.Н. Коган: «...после долгих мытарств, нашла своих родных в г. Алма-Ате, которые здесь прописаны и работают». Далее она просит: «Я твердо надеюсь, что теперь советская власть окажет мне справедливость и разрешит мне прописку в г. Алма-Ате, где я будучи квалифицированной работницей обеспечена работой и где я не буду разлучена с моими родными, иначе мне суждено погибнуть» [9, л. 77].

Обычно документы на право эвакуации выдавались эвакуационными пунктами, но местные советы также их выдавали, причем в этих документах часто не указывался определенный пункт, а писалось «вглубь страны». В этой связи в докладной записке уполномоченного КПК ВКП(б) выражалось недовольство тем, что некоторые эвакуированные «разъезжают по многим городам, разыскивая своих эвакуированных родственников, или проживающих в данной местности и нередко бесплатно, за счет государства гастролируют из одного города в другой в поисках более лучших условий жизни». При этом «...создавая встречные потоки из области в область, вплоть до тех мест, откуда происходит эвакуация, перегружают железнодорожные станции, особенно при крупных городах...» [14, л. 85-86].

Проливает свет на повседневную жизнь эвакуированных женщин заявление М.С. Тациенко от 16.04.1943 г. заместителю Народного комиссара социального обеспечения: «Убедительно Вас прошу рассмотреть мое заявление и все-таки удовлетворить мою просьбу. Я Вас прошу учесть мое плохое материальное положение. Представьте себе, что я эвакуированная и у меня ничего нет с одежды и обуви. Если Вас просила помочь мне приобрести обувь в зимнее время, когда ходила босая, Вы мне отказали. Теперь я попрошу Вас уволить меня с работы, за лето я сумею при- обрести ее, работая в другом месте, так как мне нечего надеяться на кого-то, нужно думать самой о себе, а от моей просьбы ничего не получила, кроме обострения отношений Ваших ко мне. С питанием дело обстоит тоже не лучше: столовой никакой не пользуюсь, дома продуктов тоже нет. Одним словом, живу только на хлебную карточку. Мне очень трудно жить и работать в таких условиях. Я решила, пока не поздно, пойти в совхоз и там работать» [7, л. 42].

По всей видимости, М.С. Тациенко, будучи сотрудницей Комиссариата социального обеспечения КазССР, получала маленькую зарплату, и уход на другую работу мог бы поспособствовать улучшению ее материального положения. На заявлении стоит резолюция Губанова «В приказ. Уволить с 18.04.1943 г.» [7, л. 42].

В г. Алма-Ате нашли пристанище как простые советские граждане, так и представители номенклатуры, представители творческой интеллигенции и ученые. В город прибыло 127 сотрудников Академии наук СССР, в том числе 6 академиков, 4 члена-корреспондента, 15 докторов и 35 кандидатов наук [28]. Эвакуировались 10 научно-исследовательских институтов, высших и среднетехнических заведений $[17$, л. 1]. Среди эвакуированных в Алма-Ату были известные актеры, лауреаты Сталинской премии Михаил Жаров, Николай Черкасов, Николай Крючков, Марина Ладынина, Любовь Орлова, Борис Чирков, поэты Самуил Маршак и Сергей Михалков, режиссеры Иван Пырьев, Сергей Эйзенштейн, Всеволод Пудовкин, Григорий Александров, Сергей Герасимов, Тамара Макарова, писатель Михаил Зощенко, художник Порфирий Крылов (Кукрыниксы) и другие. Работники и члены семей «Мосфильма» в количестве 118 человек были размещены в доме отдыха «15 лет Октября» (Медео) [28].

Большинство из представителей творческой интеллигенции особо отмечали необыкновенную красоту города. Михаил Ромм, начальник Управления по производству художественных фильмов СССР, в одном из своих выступлений задавался вопросом «Почему, эвакуируясь, мы выбрали Алма-Ату? Да потому что здесь 365 солнечных дней в году. Столица Казахстана предоставила нам все, что могла: только что построенный и един- 
ственный в городе Дворец культуры, где начал работать Театр оперы и балета (зрительный зал его киношники тут же превратили в большой съемочный павильон), самую крупную гостиницу, новый жилой дом, около тысячи ордеров на уплотнение, кинотеатр “Алатау” и территорию для натурных съемок. И это все в тот трудный час, когда Алма-Ата должна была разместить промышленность, десятки учреждений и организаций, тысячи эвакуированных, а потом и раненых. Следовательно, мы предъявили этому маленькому городу огромный и тяжелый счет» [2, с. 58]

Большой приток эвакуированного населения в г. Алма-Ату привел к ухудшению жилищных условий населения, к проблемам в удовлетворении насущных потребностей в пище и одежде, к повышению цен на рынках.

Кинорежиссер Георгий Натансон вспоминал: «В ноябре 1941 г. ВГИК был эвакуирован в Алма-Ату. Город Алма-Ата, раскинувшийся на фоне заснеженных гор Алатау, покорил мое сердце своею красотой. Жили трудно. На базаре было все, но стоило безумно дорого. Нам, студентам, выдавали хлеб по рабочим карточкам. Хорошо жили только студенты-художники. Они рисовали поддельные хлебные карточки, да рисовали так, что за все время эвакуации никто из них не попался. Буханки хлеба они продавали на рынке и могли позволить себе покупать и мясо, и рис, и знаменитые алмаатинские яблоки. Все студенты жили в помещении кинотехникума, где и проходили занятия. Кинотехникум располагался в предгорье Алатау. По двум сторонам улицы текли арыки с чистой горной водой. В столовой общежития можно было поесть “затируху" (галушки, наполовину сделанные из отрубей). Мама и сестра жили в съемной хибарке у реки Алма-Атинка» [13, с. 12-13].

В своем письме к сыну К. Паустовский 16 февраля 1942 г. писал: «Алма-Ата - необыкновенно красивый город, весь в садах, у подножья Тянь-Шаня, но все здешние красоты не радуют. Все живем только надеждой и ожиданием. Здесь все киноорганизации (Мосфильм, Ленфильм и др.). Здесь из писателей Зощенко (очень угрюмый), Шкловский, Ильин, Шторм, Панферов, Коля Харджиев (ты его, должно быть, помнишь), Любимова, Каплер и несколько др. Киношники все здесь - во гла- ве с Эйзенштейном. Живем мы в квартире у казахского писателя, здешнего классика Ауэзова, в крошечной комнате» [2, с. 66].

Таким образом, тыловой город АлмаАта стал на время пристанищем для десятков тысяч человек, многие из которых старались быть полезными городу и его жителям, которые, за редким исключением, отдавали буквально последнее, чтобы оказавшиеся вдали от дома, или даже оставшиеся без него, чувствовали себя как дома.

Эвакуированные госпитали. В соответствии с Постановлением ГКО СССР от 22 сентября 1941 г. с 1 октября 1941 г. при Наркомздраве КазССР было организовано Управление эвакогоспиталей со штатом 10 человек, начальником был назначен зам. Наркомздрава КазССР В.Т. Ермолаев. С 1 октября 1941 г. в 12 областях и в г. Алма-Ате были организованы отделы эвакогоспиталей $[16$, л. 1]. По документам ЦГА РК в Алма-Ате были размещены восемь эвакуированных госпиталей на 4200 коек [17, л. 1]. Согласно данным Архива Президента РК в г. Алма-Ате были размещены 9 эвакогоспиталей: № 1279, № 1280, № 1797, № 3582, № 3990, № 3991; эвакогоспитали ВЦСПС № 4091, № 4113, № 3219 [16, л. 9]. Руководителями были: И.А. Орлов № 1279, В.А. Михайлюк - № 1280, Л.М. Пруцес - № 1797, И.М. Кучерявый - № 3582, А.И. Зюзин - № 3990, А.Г. Мусатова № 3991; эвакогоспитали ВЦСПС возглавляли Э.К. Боровик - № 4091, Е.П. Скуратова № 4113, П.Ч. Вакхевич - № 3219 [23, л. 201]. Трое из девяти начальников эвакогоспиталей были женщины.

Наряду с оказанием медицинской помощи в госпиталях большое внимание уделялось политико-пропагандистской работе. Проводились лекции, доклады, беседы как работниками госпиталя, так и комсомольцами и «беспартийным активом», лекторским составом Дома партийного просвещения и райкома партии. В госпитале № 1280 в апреле - мае 1942 г. отличились девушки-комсомолки училища связи, которые провели 14 лекций, 6 докладов на военно-политические темы. Показывались кинокартины, концерты, устраивались литературные вечера силами Облкино, драмтеатра (кинокартин - 8, концертов - 9, литературных вечеров - 8). Раненые регулярно 
снабжались газетами и журналами. В каждом отделении имелись чтецы и агитаторы [11, л. 27]. Помимо политической составляющей, в Алма-Атинском Гарнизонном госпитале № 1279 были прочитаны 4 общие лекции по вопросам медицины, 8 лекций по вопросам истории Казахской Республики [4, л. 35].

В повседневной жизни госпиталей имели место и отдельные нарушения дисциплины со стороны раненых и больных. Наиболее характерные - самовольный выход в город и употребление спиртного. Примечательно, что за «10-часовую самовольную отлучку в город» на раненых было наложено взыскание, тогда как за употребление спиртного не было взыскания [11, л. 27].

Большую помощь госпиталям оказывали жены командиров, эвакуированные в Казахстан, так называемые «общественницы». Хотя встречались некоторые случаи, которые могут вызвать как улыбку, так и сожаление. В частности, «...жена командира тов. Остапенко 8/XI-41 г. в 3 ч. ночи во время дежурства приголубила бойца, больного тов. Никитенко, дело дошло до поцелуев. Кроме того, тов. Остапенко набрала денег у бойцов, санитарок, обещала купить кому папирос, кому галоши, и, конечно обманула всех - деньги не вернула» [4, л. 38].

Трудовая дисциплина была соответствующей военному времени. Так, санитарке Ушаковой был объявлен выговор за халатное отношение к работе, медсестра Машкова была уволена за сон во время дежурства, санитарка Котельникова - уволена «за принос водки и за появление на работе в пьяном виде...» и т. д. [11, л. 27 об.]. На это ужесточение дисциплины обращает внимание в своей работе Ш. Фицпатрик [25, с. 15]. В госпиталях отдельно учитывались раненые и больные, находившиеся в плену и в окружении. В материалах по эвакогоспиталю № 1280 упоминается случай с раненым по фамилии Лев, «...который афишировал себя "Герой Советского Союза", капитаном летчиком-истребителем. В результате проверки выяснилось, Лев А.А. являлся рядовым красноармейцем, беспартийным, в Красной армии никогда не служил, мобилизован в июле месяце. Во время бомбежки г. Котовска был контужен, находился на излечении в нескольких госпиталях. В нашем госпи- тале был разоблачен. Комиссией признан негодным к военной службе с переосвидетельством через 6 мес.» [11, л. 27].

После нахождения определенного срока в госпиталях, раненые и больные, по их излечении, выписывались, при этом некоторые из них, в связи с получением инвалидности, или недостаточно окрепшие, не направлялись в Красную армию. У некоторых выписавшихся возникали проблемы с адаптацией в городе. В справке зам. наркома внутренних дел КазССР по милиции Беланова от 20 мая 1942 г. отмечается: «Указанный контингент лиц, выписывающихся из госпиталей, не имея в г. Алма-Ате и в пределах КазССР родственников и в своей части не получая со стороны военведа должного содействия в части их трудоустройства и снабжения, сращивается с преступной средой и деклассируется, совершая в ряде случаев уголовные преступления. Наиболее распространенными видами уголовных преступлений являются: спекуляция промышленными и сельскохозяйственными товарами и продуктами, имущественные преступления - кражи, грабежи, а также хулиганство» [24, л. 1-2].

Необходимо отметить то, что ситуация с положением инвалидов войны находилась под особым контролем. Руководство республики, во главе с первым секретарем ЦК Компартии Казахстана Н.А. Скворцовым, придавало большое значение проблемам бытового обслуживания, обучения, трудоустройства и выдвижения инвалидов на руководящую работу. Этот вопрос стоял настолько остро, что являлся одной из причин освобождения от должности наркома социального обеспечения С.Р. Иктисамовой (июль 1938 - апрель 1943 г.). В небольшом по объему документе т. Алексееву с грифом ЛС (к протоколу заседания бюро ЦК КП(б) К от 17 марта 1943 г.) значится: «Скворцов: Помоему, есть необходимость освободить от работы тов. Иктисамову. Сейчас этот участок работ тяжелый и беспокойный. У т. Иктисамовой не получается твердого руководства, она не может взять в руки аппарат. По заявлениям в Наркомате дела решают рядовые люди и за спиной т. Иктисамовой решаются большие и малые дела. А она фактически руководителем наркомата не является, особенно сейчас. Тов. Иктисамовой надо дать участок поменьше» [15, л. 94]. 
На основе анализа текста данного документа можно отметить наличие гендерных стереотипов, связанных со слабостью и мягкостью женщин, и циркуляцию слухов во властных кругах, что следует из «по заявлениям в Наркомате». На самом деле из четырех наркомов женщин, возглавлявших народный комиссариат социального обеспечения, наиболее длительный период работы был у С.Р. Иктисамовой, которая на протяжении пяти сложнейших лет, с 1938 по 1943 г., возглавляла ведомство. В целом, со дня образования народного комиссариата социального обеспечения в октябре 1920 г. до 13 марта 1946 г., когда он был преобразован в Министерство социального обеспечения КазССР, им руководили 12 народных комиссаров. Примечательно, что в столь трудные для становления системы социального обеспечения годы 4 наркома были женщины. Это: Е.С. Хлыновская (сентябрь 1928 - март 1931 г.), А.Н. Ворожеева (июнь 1931 - июль 1932 г.), Н.И. Арыкова (июнь 1937 - июль 1938 г.), С.Р. Иктисамова (июль 1938 - апрель 1943 г.) [12, с. 22-23].

Трудовой энтузиазм. С первых дней войны алмаатинцы создали Фонд обороны, за период войны горожане внесли в оборонный фонд из личных сбережений 8,5 млн рублей $[17$, л. 2$]$. Не остались в стороне и дети, алма-атинские школьники в своем письме на фронт в 1942 г. писали: «Летний отдых мы радостно провели на хлебных полях, в уборке нашего обильного урожая, помогали в сборе овощей, фруктов. Свои трудодни мы отдали в фонд обороны. Вернувшись в город, мы собирали металлолом, а затем теплые вещи для наших родных бойцов» $[29$, л. 9].

В Алма-Ате, как и в целом по всей республике, наблюдался небывалый подъем, соревнования разворачивались под лозунгом «Все для фронта - все для Победы!». Среди перевыполнивших за 10 месяцев 1941 г. план выпуска продукции предприятий Наркомата легкой промышленности КазССР были: Алма-Атинская обувная мастерская - 102,2 \%; Алма-Атинская швейная мастерская индпошива - 127,6 \%; Алма-Атинская меховая фабрика - 104,0\%.

Для увеличения выпуска продукции в военное время помимо введения обязательных сверхурочных от 1 до 3 часов работы в день, по решению комсомольских организа- ций и общественности, были также отработаны воскресные дни в фонд обороны страны.

Лучшими предприятиями, успешно выполнявшими задачи правительства по увеличению выпуска продукции, являлись АлмаАтинский шорно-сыромятный завод и АлмаАтинская швейная фабрика № 1. Алмаатинцы проявляли в военное время самоотверженность и трудовой энтузиазм. Необходимо отметить стахановцев Алма-Атинского шорносыромятного завода Т.Н. Мокеева, выполнявшего норму на $347 \%$, А.Н. Васюкова - на $237 \%$. Стахановцами Алма-Атинской швейной фабрики № 1 были Н. Новикова, превысив норму выработки на $250 \%$; М. Шук $220 \%$; А. Шук - 300 \%; Евтифеева - 200210 \%; Мурзабекова - 130-140 \%; Найдина до $140 \%$ [27, л. 233-234].

Результаты. Война нарушила привычный образ жизни всех советских людей. Уровень жизни катастрофически снижался. Появились большие проблемы в удовлетворении насущных потребностей в жилье, пище, одежде. Обыденные вопросы, такие как чем накормить себя и свою семью, во что одеть, чем постирать, где взять дров и прочие, в условиях тотального дефицита и дороговизны стали просто не разрешимой задачей военной повседневности для большинства горожан.

Прибытие в Алма-Ату большого количества эвакуированных не только резко ухудшило жилищные условия населения, но и до предела обострило их предвоенное состояние. Для большинства советских граждан и в довоенное время были характерны достаточно аскетические условия быта. Центральное отопление, водопровод, канализация, электрическое освещение, наличие отдельной кухни были показателем повышенного комфорта. Жилищные условия зачастую не соответствовали санитарным нормам. Простым горожанам пришлось мужественно переносить все тяготы военного времени как на работе, так и в быту, в семье.

В 1943 г. началась реэвакуация, в связи с чем количество эвакуированных в республике и в г. Алма-Ате начало сокращаться. Часть эвакуированного населения остались в республике, став частью полиэтничного Казахстана.

Таким образом, в условиях ограниченности материальных и людских ресурсов, го- 
сударственным, партийным, местным органам власти Казахстана в военное время потребовалось одновременно решать задачи мобилизации людских и транспортных ресурсов, оборонного строительства, приема и обустройства значительного количества эвакуированных граждан, предприятий и учреждений, с чем они, как и жители других городов тыла, справились, дав кров и пищу, одежду и жилье тем, кто был эвакуирован в Алма-Ату.

\section{ПРИМЕЧАНИЕ}

${ }^{1}$ Статья написана в рамках реализации научно-исследовательского проекта по гранту Министерства образования и науки Республики Казахстан (МОНРК) № AP 05133556.

The reported article is carried out in the framework of the research project on the grant of the Ministry of Education and Science of the Republic of Kazakhstan (MES RK) no. AP 05133556.

\section{СПИСОК ЛИТЕРАТУРЫ}

1. В целях быстрейшего очищения города от социально-вредных элементов // Архив Президента Республики Казахстан (АП РК). - Ф. 725. - Оп. 4. Д. 196. - Л. 19.

2. Григорьев, И. А. Эвакуация в Алма-Ату / И. А. Григорьев // История. Память. Люди : материалы VII Междунар. науч.-практ. конф. 19 сент. 2014 г., г. Алматы. - Алматы, 2015. - 532 с.

3. Докладная записка // АП РК. - Ф. 708. Оп. 5/1.-Д. 1121. - Л. 71.

4. Докладная о работе Алма-Атинского Гарнизонного госпиталя № 1279 // АП РК. - Ф. 725. Оп. 4. - Д. 199. - Л. 35-38 об.

5. Докладная записка // АП РК. - Ф. 725. Оп. 4. - Д. 202. - Л. 44- 49.

6. Жаркынбаева, Р. С. Великая Отечественная война: социокультурная память и коммеморативные практики в постсоветском Казахстане (гендерный аспект) / Р. С. Жаркынбаева // Женщина в российском обществе. - 2017. - № 1 (82). - С. 103-116.

7. Заявление // Центральный государственный архив Республики Казахстан (ЦГА РК). Ф. 90. - Оп. 1. - Д. 11. - Л. 42.

8. Заявление // АП РК. - Ф. 725. - Оп. 4. Д. 227. - Л. 176-176 об.

9. Заявление // ЦГА РК. - Ф. Р 1137. - Оп. 9. Д. 150. - Л. 71-77.

10. Лебина, Н. Советская повседневность: нормы и аномалии. От военного коммунизма к боль- шому стилю / Наталия Лебина. - М. : Новое литературное обозрение, 2015. - 488 с.

11. Материал по эвакогоспиталю 1280 // АП РК. - Ф. 725. - Оп. 4. - Д. 361. - Л. 27-27 об.

12. Наркомы Казахстана 1920-1946 гг. Биографический справочник / сост. М. Ж. Жакыпов, А. С. Зулкашева, А. Н. Ипмагамбетова, Е. В. Чиликова. - Алматы : Арыс, 2007. - 400 с.

13. Натансон, Г. Г. 320 страниц про любовь и кино. Мемуары последнего из могикан / Г. Г. Натансон. - М. : Астрель, 2013. - С. 12-13. - Электрон. текстовые дан. - Режим доступа: http://modernlib.ru/ books/georgiy_natanson/320_stranic_pro_lyubov_ i_kino_memuari_poslednego_iz_mogikan/read_ $\overline{1 /}$ (дата обращения: 10.01.2019). - Загл. с экрана.

14. О недостатках в работе эвакопунктов в деле передвижения эвакуированных // АП РК. - Ф. 725. Оп. 4. - Д. 194. - Л. 85-91.

15. О состоянии политико-воспитательной работы, бытовому обслуживанию, трудобучению, трудоустройстве и выдвижении инвалидов Отечественной войны на руководящие работы // АП РК. Ф. 708. - ОП. 7/1. - Д. 965. - Л. 94.

16. Об организации Управления эвакогоспиталей при Наркомздраве КазССР // АП РК. - Ф. 708. Оп. 5/2. - Д. 193. - Л. 1-9.

17. Предисловие // Национальный архив РК (НА РК). - Ф. 79. - Оп. 1. - Д. 44. - Л. 1-2.

18. Призыв женщин-общественниц г.Алма-Ата // АП РК. - Ф. 708. - ОП. 6/1. - Д. 483. - Л. 21.

19. Сведения о прибытии в г. Алма-Ата эвакуированных граждан на 29.08.1941 г. // ЦГА РК. Ф. Р-1137. - Оп. 9. - Д. 141. - Л. 70.

20. Сводка о количестве прибывшего эвакуированного населения в Казахскую ССР и его трудоустройству по состоянию на 1 марта 1943 г. // АП РК. - Ф. 708. - ОП. 7/1. - Д. 748. - Л. 2.

21. Справка о состоянии прибывшего оборудования и людей на станцию Алма-Ата Отрожского вагоноремонтного завода им. Тельмана // АП РК. - Ф. 725. - ОП. 4. - Д. 194. - Л. 116-121.

22. Справка о штатном и фактическом наличии работников в эвакопунктах КазССР на 01.03.1943 г. // АП РК. -Ф. 708. - Оп. 7/1. - Д. 748. - Л. 14.

23. Список госпиталей, расположенных в гор.Алма-Ата // АП РК. - Ф. 708. - ОП. 5/2. - Д. 188. Л. 201.

24. Уполномоченному КПК по КазССР тов. Кузнецову. Справка // АП РК.-Ф. 725. - Оп. 4. - Д. 361. Л. 1-2.

25. Фицпатрик, Ш. Повседневный сталинизм. Социальная история Советской России в 30-е годы: город/ Ш. Фицпатрик. - М. : РОССПЭН, 2008.-336 с.

26. Хлынина, Т. П. Частная жизнь советского человека в условиях военного времени как исследовательский проект / Т. П. Хлынина // Былые годы. 
Российский исторический журнал. - 2012. № 3 (25). - С. 98-105.

27. ЦК КП(б) Казахстана. Отдел общей промышленности // АП РК. -Ф. 708. - Оп. 5/1.-Д. 738. Л. 233-234.

28. Шепель, В. Алмаатинцы в годы войны: рассекреченная правда / В. Шепель // Вечерний Алматы. $-2009 .-8$ окт.

29. Юныепатриоты// АПРК.-Ф. 708.-Оп. 6/1.Д. $483 .-$ Л. 9.

\section{REFERENCES}

1. $\mathrm{V}$ tselyakh bystreyshego ochishcheniya goroda ot sotsialno-vrednykh elementov [In Order to Quickly Cleanse the City of Socially Harmful Elements]. Arkhiv Prezidenta Respubliki Kazakhstan (AP RK) [Archive of the President of the Republic of Kazakhstan], F. 725, Op. 4, D. 196, L. 19.

2. Grigoryev I.A. Evakuatsiya v Alma-Atu [Evacuation to Alma-Ata]. Istoriya. Pamyat. Lyudi: materialy VII Mezhdunar. nauch.-prakt. konf. 19 sent. 2014 g., g. Almaty [History. Memory. People. Proceedings of the $7^{\text {th }}$ International Scientific and Practical Conference, September 19, 2014, Almaty]. Almaty, 2015. $532 \mathrm{p}$.

3. Dokladnaya zapiska [Memo]. AP RK [Archive of the President of the Republic of Kazakhstan], F. 708, Op. 5/1, D. 1121, L. 71.

4. Dokladnaya o rabote Alma-Atinskogo Garnizonnogo gospitalya № 1279 [Report on the Work of the Alma-Ata Garrison Hospital no. 1279]. AP RK [Archive of the President of the Republic of Kazakhstan], F. 725, Op. 4, D. 199, L. 35-38 ob.

5. Dokladnaya zapiska [Memo]. AP RK [Archive of the President of the Republic of Kazakhstan], F. 725, Op. 4, D. 202, L. 44-49.

6. Zharkynbayeva R.S. Velikaya Otechestvennaya voyna: sotsiokulturnaya pamyat i kommemorativnye praktiki v postsovetskom Kazakhstane (gendernyy aspekt) [The Great Patriotic War: Sociocultural Memory and Commemorative Practices in Post-Soviet Kazakhstan (Gender Aspect)]. Zhenshchina $v$ rossiyskom obshchestve [Woman in Russian Society], 2017, no. 1 (82), pp. 103-116.

7. Zayavlenie [Statement]. Tsentralnyy gosudarstvennyy arkhiv Respubliki Kazakhstan (TSGA RK) [Central State Archive of the Republic of Kazakhstan], F. 90, Op. 1, D.11, L. 42.

8. Zayavlenie [Statement]. AP RK [Archive of the President of the Republic of Kazakhstan], F. 725, Op. 4, D. 227, L. 176-176 ob.

9. Zayavlenie[Statement]. TsGARK [Central State Archive of the Republic of Kazakhstan], F. R 1137, Op. 9, D. 150, L. 71-77.
10. Lebina N. Sovetskaya povsednevnost: normy $i$ anomalii. Ot voennogo kommunizma $k$ bolshomu stilyu [Soviet Everyday Life: Norms and Anomalies. From War Communism to Great Style]. Moscow, Novoe literaturnoe obozrenie Publ., 2015. 488 p.

11. Material po evakogospitalyu 1280 [Material for Evacuation Hospital 1280]. AP RK [Archive of the President of the Republic of Kazakhstan], F. 725, Op. 4, D. 361, L. 27-27 ob.

12. Zhakypov M.Zh., Zulkasheva A.S., Ipmagambetova A.N., Chilikova E.V., eds. Narkomy Kazakhstana 1920-1946 gg. Biograficheskiy spravochnik [People's Commissars of Kazakhstan 1920-1946. Biographical Reference]. Almaty, Arys Publ., 2007. 400 p.

13. Natanson G.G. 320 stranits pro lyubov $i$ kino. Memuary poslednego iz mogikan [320 Pages About Love and Movies. Memoirs of the Last of the Mohicans]. Moscow, Astrel Publ., 2013, pp. 12-13. URL: http://modernlib.ru/books/georgiy natanson/ 320 stranic pro_lyubov_i kino_memuari poslednego iz_mogikan/read_1/(accessed 10 January 2019).

14. O nedostatkakh $\mathrm{v}$ rabote evakopunktov $\mathrm{v}$ dele peredvizheniya evakuirovannykh [On the Shortcomings in the Work of Evacuation Centers in the Movement of the Evacuated]. AP RK [Archive of the President of the Republic of Kazakhstan], F. 725, Op. 4, D. 194, L. 85-91.

15. O sostoyanii politiko-vospitatelnoy raboty, bytovomu obsluzhivaniyu, trudobucheniyu, trudoustroystve i vydvizhenii invalidov Otechestvennoy voyny na rukovodyashchie raboty [On the State of Political and Educational Work, Consumer Services, Labor Training, Employment and the Promotion of Invalids of World War II for Leadership Positions]. APRK [Archive of the President of the Republic of Kazakhstan], F. 708, Op. 7/1, D. 965, L. 94.

16. Ob organizatsii Upravleniya evakogospitaley pri Narkomzdrave KazSSR [On the Organization of the Office of Evacuation Hospitals Under the People's Commissariat of Health of the Kazakh SSR]. AP RK [Archive of the President of the Republic of Kazakhstan], F. 708, Op. 5/2, D. 193, L. 1-9.

17. Predislovie [Foreword]. Natsionalnyy arkhiv $R K$ (NA RK) [National Archive of the Republic of Kazakhstan], F. 79, Op. 1, D. 44, L. 1-2.

18. Prizyv zhenshchin-obshchestvennits g. AlmaAta [Call of Women Social Activists in Alma-Ata]. $A P$ $R K$ [Archive of the President of the Republic of Kazakhstan], F. 708, Op. 6/1, D. 483, L. 21.

19. Svedeniya o pribytii v g. Alma-Ata evakuirovannykh grazhdan na 29.08.1941 g. [Information on the Arrival of Evacuated Citizens in Alma-Ata on August 29, 1941]. Ts GA RK [Central State Archive of the Republic of Kazakhstan], F. R-1137, Op. 9, D. 141, L.70. 
20. Svodka o kolichestve pribyvshego evakuirovannogo naseleniya v Kazakhskuyu SSR i ego trudoustroystvu po sostoyaniyu na 1 marta $1943 \mathrm{~g}$. [Summary of the Number of the Arrived Evacuated Population in the Kazakh SSR and Its Employment as of March 1, 1943]. AP RK [Archive of the President of the Republic of Kazakhstan], F. 708, Op. 7/1, D. 748, L. 2.

21. Spravka o sostoyanii pribyvshego oborudovaniya i lyudey na stantsiyu Alma-Ata Otrozhskogo vagonoremontnogo zavoda im. Telmana [Information on the Condition of the Equipment and People Who Arrived at the Alma-Ata Station of the Otrozhsky Car Repair Plant Named After Telman]. AP $R K$ [Archive of the President of the Republic of Kazakhstan], F. 725, Op. 4, D. 194, L. 116-121.

22. Spravka o shtatnom i fakticheskom nalichii rabotnikov v evakopunktakh KazSSR na 01.03.1943g. [Certificate of Staffing and Actual Availability of Workers in the Evacuation Centers of the Kazakh SSR as of March 1, 1943]. AP RK [Archive of the President of the Republic of Kazakhstan], F. 708, Op. 7/1, D. 748, L. 14.

23. Spisok gospitaley, raspolozhennykh $\mathrm{v}$ gor. Alma-Ata [List of Hospitals Located in the City of Alma-Ata]. AP RK [Archive of the President of the Republic of Kazakhstan], F. 708, Op. 5/2, D. 188, L. 201.
24. Upolnomochennomu KPK po KazSSR tov. Kuznetsovu. Spravka [To the Authorized Representative of the Commission of Party Control in KazSSR Comrade Kuznetsov. Reference]. $A P R K$ [Archive of the President of the Republic of Kazakhstan], F. 725, Op. 4, D. 361, L. 1-2.

25. Fitspatrik Sh. Povsednevnyy stalinizm. Sotsialnaya istoriya Sovetskoy Rossii v 30-e gody: gorod [Everyday Stalinism. Social History of Soviet Russia in the 30s: City]. Moscow, ROSSPEN Publ., 2008. 336 p.

26. Khlynina T.P. Chastnaya zhizn sovetskogo cheloveka $\mathrm{v}$ usloviyakh voennogo vremeni kak issledovatelskiy proekt [Private Life of Soviet People in Wartime as a Research Project]. Bylye Gody, 2012, vol. 25 , no. 3, pp. $98-105$.

27. TSK KP/b/Kazakhstana. Otdel obshchey promyshlennosti [Central Committee of the Communist Party (Bolsheviks) of Kazakhstan. Department of General Industry]. APRK [Archive of the President of the Republic of Kazakhstan], F. 708, Op. 5/1, D. 738, L. 233-234.

28. Shepel V. Almaatintsy v gody voyny: rassekrechennaya pravda [Almaty Residents During the War: Declassified Truth]. Vecherniy Almaty, 2009, October 8.

29. Yunye patrioty [Young Patriots]. $A P R K$ [Archive of the President of the Republic of Kazakhstan], F. 708, Op. 6/1, D. 483, L. 9.

\section{Information About the Authors}

Roza S. Zharkynbayeva, Doctor of Sciences (History), Professor, Department of World History, Historiography and Source Studies, Al-Farabi Kazakh National University, Prosp. Al-Farabi, 71, 050040 Almaty, Republic of Kazakhstan, r_seidali@mail.ru, https://orcid.org/0000-0001-8560-1654

Nadezhda V. Dulina, Doctor of Sciences (Sociology), Professor, Department of Sociology and Social Technologies, Volgograd State University, Prosp. Universitetsky, 100, 400062 Volgograd, Russian Federation,nv-dulina@yandex.ru,nv-dulina@volsu.ru,https://orcid.org/0000-0002-6471-7073

Evgeniya V. Anufrieva, Candidate of Sciences (Philosophy), Associate Professor, Department of History, Culture and Sociology, Volgograd State Technical University, Prosp. im. V.I. Lenina, 28, 400005 Volgograd, Russian Federation, ev_anufrieva@mail.ru, https://orcid.org/0000-0002-0756-4488

\section{Информация об авторах}

Роза Сейдалиевна Жаркынбаева, доктор исторических наук, профессор кафедры всемирной истории, историографии и источниковедения, Казахский национальный университет им. альФараби, просп. аль-Фараби, 71, 050040 г. Алматы, Республика Казахстан, r_seidali@mail.ru, https://orcid.org/0000-0001-8560-1654

Надежда Васильевна Дулина, доктор социологических наук, профессор кафедры социологии и социальных технологий, Волгоградский государственный университет, просп. Университетский, 100, 400062 г. Волгоград, Российская Федерация, nv-dulina@yandex.ru, nv-dulina@volsu.ru, https://orcid.org/0000-0002-6471-7073

Евгения Владимировна Ануфриева, кандидат философских наук, доцент кафедры истории, культуры и социологии, Волгоградский государственный технический университет, просп. им. В.И. Ленина, 28, 400005 г. Волгоград, Российская Федерация, ev_anufrieva@mail.ru, https://orcid.org/0000-0002-0756-4488 